\title{
Compromisso com a qualidade
}

\author{
Commitment to quality
}

\author{
Renato S. Procianoy*
}

\begin{abstract}
Ao assumir a função de editor-chefe do Jornal de Pediatria, sinto-me compromissado com os leitores, com o grupo do qual faço parte, e com a Sociedade Brasileira de Pediatria.

Desde 1994, quando fui convidado pelo Dr. Jefferson Piva a colaborar no novo Conselho Editorial do Jornal de Pediatria, o nosso grupo sonhava com uma revista científica pediátrica que tivesse um padrão editorial equivalente às melhores publicações internacionais. Foram oito anos de trabalho árduo, reuniões quinzenais, mais de mil artigos revisados. O Jornal de Pediatria se transformou na revista de eleição do pediatra brasileiro. Nos últimos quatro anos o número de artigos submetidos à publicação cresceu significativamente, tendo possibilitado o aumento do número de artigos originais por fascículo, sem comprometer a qualidade do material publicado. Com o objetivo de satisfazer uma parcela importante dos leitores que solicitavam mais artigos de revisões, foram criados dois suplementos anuais, com editores e autores especialmente convidados.
\end{abstract}

A criação do jornal eletrônico (www.jped.com.br) que veicula os artigos do Jornal de Pediatria em dois idiomas (português e inglês) está possibilitando a internacionalização da nossa produção científica. São milhares de acessos mensais (entre 300 a 500 por dia), dos mais variados países.

Esse esforço resultou num reconhecimento dos diversos órgãos avaliadores das publicações científicas. O Jornal de Pediatria foi qualificado como Publicação Nacional A pela CAPES, foi incluído na base de dados bibliográficos do SciELO e está indexado no Embase. A manifestação de satisfação dos leitores, que recebem uma revista com informações selecionadas e atualizadas, e a dos autores, que têm o seu material de pesquisa publicado numa revista de reconhecida qualidade, tem sido recompensadora.

Os méritos dessas conquistas são atribuídos: ao editorchefe, Dr. Jefferson Piva, que trabalhou intensamente, tendo sido extremamente dedicado e responsável nas suas atribuições; ao Conselho Editorial, que teve uma participa- ção ativa nas decisões tomadas; à Diretoria da SBP, que deu todo o suporte necessário; e aos revisores independentes dos artigos, que responderam à solicitação de colaboração. $\mathrm{O}$ momento pelo qual está passando a Pediatria brasileira auxiliou a nossa tarefa. A efervescência dos programas de pós-graduação propiciou a produção de muitas pesquisas de alta qualidade nas universidades brasileiras, e, com isso, a oferta de material aumentou em número e qualidade.

A homologação do meu nome, encabeçando o atual grupo que coordena as atividades editoriais do Jornal de Pediatria como o novo editor-chefe pela "Comissão de Seleção de Editor do Jornal de Pediatria", representou um voto de confiança na atual condução da nossa revista e a aprovação de todo o nosso trabalho passado. Assumir a editoria do Jornal de Pediatria neste momento torna-se uma grande honra, e uma imensa responsabilidade. O Jornal de Pediatria é uma revista que, no momento atual, transcende a SBP, é patrimônio da comunidade científica pediátrica. A manutenção do padrão de qualidade exige um cuidado extremo. Construir é difícil, manter e aprimorar o que está muito bom é, possivelmente, mais difícil ainda.

O Jornal de Pediatria deverá fazer a ponte entre a pesquisa básica e a prática clínica na área pediátrica, trazendo novos conhecimentos, procurando informar ao leitor o que há de mais atual.

Continuamos sonhando com uma revista científica de alcance internacional que se torne referência em todos os continentes. A revista eletrônica bilíngue é o início da internacionalização. A colaboração de autores de fora do Brasil é o próximo passo a ser atingido. A colaboração dos programas de pós-graduação e de todos os pesquisadores brasileiros que cuidam de crianças e adolescentes, submetendo as suas melhores pesquisas ao Jornal de Pediatria, precisa ser mantida e incentivada.

O Jornal de Pediatria é patrimônio dos que trabalham com crianças e adolescentes e, portanto, é do interesse de todos em tê-lo conceituado e respeitado.

* Editor do Jornal de Pediatria. 